\title{
Influence of Sodium Tungstate and Sealing Treatment on Corrosion Resistance of Coatings Formed on AZ31 Magnesium Alloy by Plasma Electrolytic Oxidation
}

\author{
Wenbin Tu, Yulin Cheng, Tingyan Zhan, Junxiang Han, Yingliang Cheng * \\ College of Materials Science and Engineering, Hunan University, Changsha, 410082, China \\ *E-mail: chengyingliang@ @nu.edu.cn, deepblacksea@163.com
}

doi: $10.20964 / 2017.11 .34$

Received: 2 August 2017 / Accepted: 9 September 2017 / Published: 12 October 2017

\begin{abstract}
W-containing ceramic coatings were fabricated on AZ31 magnesium alloy by plasma electrolytic oxidation (PEO) in an aluminate-based electrolyte with the addition of sodium tungstate $\left(\mathrm{Na}_{2} \mathrm{WO}_{4} \cdot 2 \mathrm{H}_{2} \mathrm{O}\right)$. The addition of $\mathrm{Na}_{2} \mathrm{WO}_{4} \cdot 2 \mathrm{H}_{2} \mathrm{O}$ not only increased the growth rate and surface roughness of the coatings but also improved the corrosion resistance of the PEO coating. The relationship between the corrosion resistance of the PEO coating and the concentration of $\mathrm{Na}_{2} \mathrm{WO}_{4} \cdot 2 \mathrm{H}_{2} \mathrm{O}$ was studied, and the coating obtained in $10 \mathrm{~g} \mathrm{l}^{-1} \mathrm{Na}_{2} \mathrm{WO}_{4} \cdot 2 \mathrm{H}_{2} \mathrm{O}$ showed the best corrosion resistance. Ce-based sealing followed by $\mathrm{Al}\left(\mathrm{H}_{2} \mathrm{PO}_{4}\right)_{3}$ sealing treatment was further carried out to improve the corrosion resistance of the coatings. It was found that the number and size of pores and micro-cracks decreased after sealing. Potentiodynamic polarization tests and electrochemical impedance spectroscopy (EIS) measurements indicated that the corrosion resistance of the PEO coatings was effectively improved by the two-step sealing method.
\end{abstract}

Keywords: Plasma electrolytic oxidation, Magnesium alloy, Tungstate, sealing, corrosion resistance.

\section{$\underline{\text { FULL TEXT }}$}

(C) 2017 The Authors. Published by ESG (www.electrochemsci.org). This article is an open access article distributed under the terms and conditions of the Creative Commons Attribution license (http://creativecommons.org/licenses/by/4.0/). 